\title{
STRATEGIC LEADERSHIP AND PERFORMANCE OF SMALL AND MEDIUM ENTERPRISES: THE ROLE OF STRATEGIC INTERVENTIONS
}

\begin{abstract}
The study examines how strategic interventions mediate in the relationship between strategic leadership behaviors and firm performance of SMEs in Nigeria. A survey of 834 registered operators of SMEs through structured questionnaire was used and data were analysed using mediation analysis through structural equation modeling. The results showed that strategic leadership influence performance through strategic interventions decomposed into organisational learning and cultural values. It showed that the mediator exerts stronger effect on performance than the independent variable. It revealed further that strategic interventions are significant in its causal effect on performance of SMEs than strategic leadership. The implication is that the operators should not only encourage employee to be optimistic in future accomplishment and stimulate a sense of logic to create the notion of problem solving, but also must inculcate the culture of paying attention to employee talents and needs for performance improvement.
\end{abstract}

Keywords: strategic interventions, cultural change, strategic leadership, organisational learning, performance.

\section{INTRODUCTION}

The performance and competitiveness of firms such as small and medium enterprises are critical issues to owners and managers. Studies (Katila \& Shane, 2005; Ahuja \& Lampert, 2001) have raised questions on differences in performance of firms existing in the same industry with mixed outcomes. According to Arasa and K'Obonyo (2012), competitive advantage that emanates from organisational internal competencies can be safer in creating benefits for firms. Thus, leadership factor as an important aspect of

${ }^{1}$ Niyi Israel Akeke, PhD, Department of Business Administration, Ekiti State University, Ado Ekiti, Nigeria; e-mail: niyi.akeke@eksu.edu.ng (corresponding author). ORCID: 0000-0002-8622-4069.

${ }^{2}$ Hezekiah Olufemi Adetayo, PhD, Department of Business Administration, Ekiti State University, Ado Ekiti, Nigeria; e-mail: heftad4u@gmail.com. ORCID: 0000-0002-9600-6583.

${ }^{3}$ Adenike Rita Akeke, PhD student, Department of Business Education, Adeniran Ogunsanya College of Education, Nigeria; e-mail: ninikx2002@yahoo.com. ORCID: 0000-0001-5318-0736.

${ }^{4}$ Mathew Olufemi Oyebanji, PhD student, Department of Business Administration, Ekiti State University, Ado Ekiti, Nigeria; e-mail: femimat2007@ yahoo.com. ORCID: 0000-0002-5922-1794. 
organisational internal competitive superiorities, have been identified as the most important individual influences on firm success (Harborne \& Johne, 2003; Sethi, 2000). AbduiRazaq (2010) notes that the effective development of good leadership is one of the driving forces for small and medium enterprises success in the future, inadequate leadership and management skills however, are factors leading to their failure (Davies, Hides \& Powell, 2002). Further, Waidman, Ramirez, House and Puranam (2001) argue that it is possible for leaders to have substantive influence on the overall performance of the firm they lead, and that specific characteristics of managers at strategic level do indeed make a difference in strategy formulation and overall performance (Strand, 2017; Hambrick, 2007; Hambrick $\&$ Mason, 1984). This perspective of leadership is embedded in strategic management and it is called leadership of organisation (Bedeian \& Hunt, 2006) and strategic leadership (Cummings \& Worley, 2009). It constitutes the small group of people who are top executives that take absolute responsibility for the firm and whose decisions on courses of actions affect organizational outcomes (Papadakis \& Bourantas, 1998; Finkelstein \& Hambrick, 1996). The upper echelon study of Boal and Hooijberg (2001) form the foundation of strategic leadership which Bass's (1985) framework of transformational and transactional has proved to be useful in the study of people who have the overall responsibility for the organisations.

Strategic leaders are those who will take the initiatives to drive the strategic vision so that firms do not lose focus on their customers. These leaders implement change (Kotter \& Heskett, 1985), and cultural change (Dyer, 1985) that will bring a new set of assumptions and belief to the organisation. The leaders learn how to shape a firm's shared values to sustain an effective organisational culture for competitiveness (Slawinski, 2007) as well as have the power to influence the overall firm effectiveness by leveraging the firm's strength to surmount external threats for exploitation of opportunities (Yukl, 2010). Strategic leaders are value-driven, exhibit inspirational and supportive behaviours (Oladele, Akeke, Adebisi $\&$ Adeusi, 2013), and have the required cognitive and behavioural complexity necessary to translate their social intelligence into effective business performance in an ever changing organizational landscape. Strategic leadership play a significant role in gaining and maintaining competitiveness and their impact on organisational effectiveness and success is positive and significant (Safarzadeh, Dahghan, Pazireh \& Pouraskari, 2015; Yazdani, 2009; Hitt, Keats \& Demarie, 1998). Strategic leaders affecting organisational culture may as well have the capacity to affect organisational learning capacity directly (Phipps \& Burbach, 2010).

Empirical researches on the connection between strategic leadership and performance have been conflicting. While some studies indicate significant positive relationship (Quigley \& Graffin, 2017; Ireland \& Hitt, 1999), others show the magnitude of influence over performance is insignificant because their actions are impeded by many constraints (Fitz, 2017; Hareman, 1992). Thus, a lack of clear cut evidence on direct connection between strategic leadership and performance is created (Knies, Jacobsen \& Tummers, 2016). The literature has argued that critical organizational variables and internal systems such as strategic interventions in the form of organizational learning and cultural change that might mediate such relationship have received some frivolity. "Strategic interventions involve a deliberate attempt to move organisations toward a more effective state and improve performance" (McLean in Akeke, 2019). It is a long-term effort to bail out organisations because it involves organizational learning and cultural change as two organizational phenomena among organisational systems that help to build organisations 
and make them competitive Cummings \& Worley, 2009). Organisational culture is a set of values, beliefs, and behaviour patterns that forms the core identity of organisations, and help in shaping the employees' behaviour (Schein, 1992; Kotter \& Heskett, 1992). It provides a kind of cognition framework that affects how a firm's context is defined and mechanism for executing events (Jones, 1983).

Organisational culture affects employee and organisational outcomes (Abu-Jarad, Yusof \& Nikbin, 2010), employee development, learning and behaviour (Bollinger \& Smith, 2001), knowledge management (McDermontt \& O'Dell, 2011) and financial performance (Yesil \& Kaya, 2013). Rashid, Sambasivan and Johari (2003) argue that the importance of culture to organisation is likened to the personality of an individual therefore; culture is the soul that makes members act as a single entity working in the same direction. By the styles of leaders, an organisation is able to promote and reinforce a work context that facilitates learning through cultural framework (Joseph \& Dai, 2009). Therefore, as culture helps to influence how the firms conduct their businesses as well as the methods used to regulating and controlling the behaviour of organizational members, it can form a platform for learning to take place and achieve sustained performance (Akeke, 2019).

Organisational learning importance indicates that it is a need rather than a choice (Garcia-Morales, Jimenez-Barrinonuevo \& Gutierrez-Guttierez, 2011), as such, (Senge, 1990) argues that many organisations die before their forties in existence due to their inability to learn. Organisational learning is an activity which includes the creation of specific skills, dissemination of acquired skills, integrating the knowledge into the systems to become capability for improved performance (Zollo \& Winter, 2002; Dibella, Nevis \& Gould, 1996). Senge (1990), Fiol and Lyles (1985) and Namada (2017) maintain that organisational learning is a process through which individuals in organisation develop new insights that have potential for improved organisational performance. Firm performance has not only been associated with owner satisfaction and growth in terms of sales, market, profit and employment growth, but has been argued as critical elements in achieving sustained competitive advantage and profitability (Ahmad, 2014; Fitzsimmons et al., 2005; Markman \& Gartner, 2002).

Therefore, this study proposes an investigation of the influence of strategic leadership on firm performance through the mediating role of strategic interventions. Specifically, it seeks to examine how organisational learning and cultural change mediate between strategic leadership behaviors and firm performance.

\section{MATERIALS AND METHODS}

The study was carried out in the Southwest states of Nigeria. The study comprises all operators/owner-managers/CEOs of all 8,338 registered SMEs under the aegis of Ministry of Commerce and Industry in southwest, Nigeria. To ensure representativity of the sample, a multistage sampling method was used. In the first stage, only SMEs that were duly registered with the regulatory authority and in active business activities were purposively selected. The second stage involves stratification of the enterprises into small and medium enterprise. At this stage equal proportion of the enterprise group were selected. The third and the large stage involves random selection of eight hundred and thirty-four (834) SMEs. Overall, the randomly selected sample represents a sample fraction of $10 \%$. Data were collected through a survey research design using a structured 5-point Likert scale with the exception of performance measures which include nominal scale. The questionnaire was 
structured according to the major variables of strategic leadership, strategic interventions, and performance measures. The questionnaire was self-administered with the assistance of well-trained enumerators due to the volume and large areas that were covered for the study. The data collected were analysed using descriptive statistics and mediation analysis. Mediation analysis was carried out to determine the mediating role of change interventions in the relationship between strategic leadership and performance of the sample firms. The mediation analytical method was chosen because of existence of causal process between strategic leadership, interventions and performance. This selection of this method follows similar studies including Kamariah, Rahman and Kadir (2018). The mediation analysis was carried out through structural equation modeling process. The mediation analysis seeks to measure causal effect between an independent variable and a dependent variable. There are also indirect effect between independent variable and a mediator variable, and between a mediator variable and a dependent variable. The mediation analysis requires there is a significant relationship between the mediator and the independent variables.

\section{RESULTS AND DISCUSSION}

\subsection{Descriptive Statistics of the Study Variables}

The descriptive statistics of the study variables are presented in Table 1 . The variables of strategic leadership and strategic interventions and performance outcomes are presented in Table 1. The average value of strategic leadership measures is 3.57 while that of strategic interventions is 3.89. Most of the individual values of strategic interventions in SMEs are above average measure suggesting higher perception of respondents for the possible mediating contribution of change interventions on performance of small and medium businesses. Continuous learning (3.57), inquiry and dialogue (4.00), team learning (3.86), empowerment (4.30), embedded system (3.85) and system connection (3.78) are rated high by respondents as relevant strategic interventions factors in the SMEs.

Table 1. Descriptive statistics of the study variable

\begin{tabular}{|l|c|c|}
\hline & Mean & Std. Dev. \\
\hline Charismatic & 3.74 & 0.98 \\
\hline Inspirational & 2.99 & 0.99 \\
\hline Intellectual & 3.09 & 1.03 \\
\hline Individual & 3.99 & 0.81 \\
\hline Contingent & 4.02 & 0.81 \\
\hline Total average & $\mathbf{3 . 5 7}$ & $\mathbf{0 . 9 2}$ \\
\hline Continuous Learning & 3.57 & 0.59 \\
\hline Inquiry \& dialogue & 4.00 & 0.84 \\
\hline Team Learning & 3.86 & 0.91 \\
\hline Empowerment & 4.30 & 0.71 \\
\hline Embedded system & 3.85 & 0.99 \\
\hline System connection & 3.78 & 1.01 \\
\hline Total & $\mathbf{3 . 8 9}$ & $\mathbf{0 . 8 4}$ \\
\hline
\end{tabular}

Source: own study. 


\subsection{Mediation Analysis of Strategic Interventions in the Relationship between Strategic Leadership and SMEs Performance}

The results of mediation analysis are illustrated in figure 1. The estimated regression effect of the mediation analysis is presented in Table 2 . The results (Table 2) show a positive and significant effect of the variables on performance. The result shows that strategic leadership influence performance of SMEs through strategic interventions by 0.471 . This represents the value of effect independent variable and mediator on performance of the firms. In the absence of the mediator (strategic interventions), the isolated effect of strategic leadership on performance is approximately 0.35 . In the absence of strategic interventions, the isolated effect of strategic interventions is 0.11 . The results bring a lot of implications. First, the mediator (strategic interventions) exerts stronger effect on performance of the SMES than the independent variable. Clearly, strategic interventions are significant (5\%) in its causal effect on performance than strategic leadership. This corroborates Slater and Narver (1995) and Glynn (1996) that learning can assist firm to create the future because it involves the use of knowledge to facilitate performance enhancing organizational change. Second, strategic leadership also exerts significant effect on performance without the mediator-strategic interventions. Third, the combination of strategic interventions with strategic leadership brings about higher effect on the performance of the SMEs and strategic interventions clearly mediate strategic leadership and performance of SMEs. This supports Garcia-Morales et al. (2012) that strategic leaders use their behaviours to support exploratory innovation through feed-forward flows of learning by motivating organizational members to share knowledge. Therefore, firms that show a greater breadth, depth and speed of organizational learning have higher levels of performance (Hurley

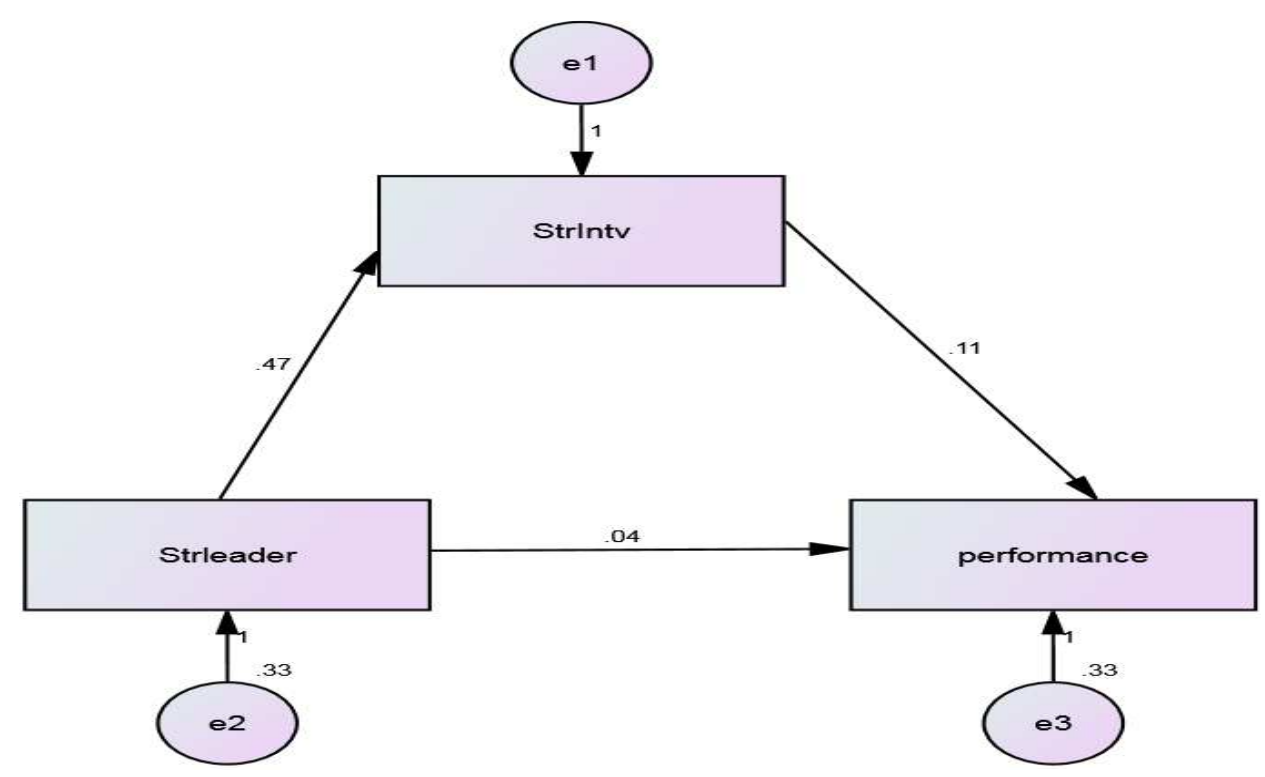

Figure 1. A diagram of mediation model Strinv= strategic interventions (strategic interventions $)$, strleader $=$ (strategic leadership)

Source: own study. 
Table 2. Regression estimates (Total effects) of mediation analysis

\begin{tabular}{|lll|rrrrr|}
\hline & & & Estimate & S.E. & C.R. & P & Label \\
\hline StrIntv & $<---$ & Strleader & .471 & .038 & 12.353 & $* * *$ & par_2 \\
performance & $<---$ & Strleader & .035 & .012 & 2.917 & $* * *$ & par_1 \\
performance & $<---$ & StrIntv & .106 & .045 & 2.325 & .020 & par_3 \\
\hline
\end{tabular}

Source: own study.

\& Hult, 1998). Additionally, organizational culture will affect organizational outcomes, learning and behavior which also provide adequate way to change (Janicijevic, 2012; Abu-Jarad et al., 2010; Bollinger \& Smith, 2001) for superior performance.

\section{CONCLUSION AND RECOMMENDATIONS}

Strategic interventions are needed by organisations for improving their performance. The study contributes to such performance improvement by showing the increasing importance of components of strategic interventions as mechanism through which strategic leadership impact SMEs performance. Past studies have maintained a direct link between strategic leadership and firm performance. The study has showed an indirect relationship between strategic leadership and performance through strategic interventions as mediating variable. The findings of the study lead to the conclusion that inspirational leadership, intellectual leadership and individual leadership mediated by continuous learning, team learning and well embedded strategic system are the important pathways to good performance in SMEs sectors. The impact of organizational learning and cultural values in organizations can be felt through the role played by strategic leadership. Culture provides a platform by which learning takes place. In addition, organizational learning and organization culture have significance on firm performance. The study recommends the need to position the future entrepreneur for strategic leadership quality through learning in order to raise the economic standard of the country via SMEs performance. The finding of the study proved that leadership structure in SMEs has been oriented towards to achieve the vision and the specific goals of the business organizations though strategic interventions. This positive and significant relationships agree with earlier studies including Safarzadeh, et al., (2015), and Yazdani, (2009). However, for large business organization, this finding is at odds as empirically proved by Kamariah, et al. (2018) in their focus on complex business structure. Overall, the study proves that leadership styles are customizable across sectors. Leadership structure is important for the overall success of small business

The study used respondents from one of the six geopolitical zones in Nigeria with similar cultural traits. This may limit its generalisation. Further research can extend to more than one zone to allow for results generalisation. Besides, time dimension is a limitation to the study because performance measures were collected on one point in time. Perhaps, further studies could do a longitudinal survey.

\section{REFERENCES}

AbdulRazaq, M. N. (2010). Keynote address by the Honorary Prime Minister at Invest Malaysia, Kuala Lumpur. 
Abu-Jarad, I. S., Yusof, N. A., Nikbin, D. (2010). A review paper on organizational culture and organizational performance. "International Journal of Business and Social Science”, 1(3).

Ahmad, F. A. (2014). Leadership and performance: The case of Malaysian SMEs in the service sector. "International Journal of Social Science", 4(3).

Ahuja, G., Lampert, C. M. (2001). Entrepreneurship in the large corporation: A longitudinal study of how established firms create breakthrough inventions. "Strategic Management Journal", 22.

Akeke, N. I. (2019). Strategic interventions and performance of small and medium enterprises in Nigeria. "International Journal of Community Development and Management Studies", 3.

Arasa, R., K'Obonyo, P. (2012). The relationship between strategic planning and firm performance. "International Journal of Humanities and Social Science”, 2(22).

Bedeian, A., Hunt, J. (2006). Academic amnesia and vestigial assumptions of our forefathers. "Leadership Quarterly", 17(2).

Bollinger, S. A., Smith, R. D. (2001). Managing organizational knowledge as a strategic asset. "Journal of Knowledge Management", 5(1).

Cummings, T. G., Worley, C. G. (2009). Organisation Development and Change. Mason: South Western.

Davies, J., Hides, M., Powell, J. (2002). Defining the development needs of entrepreneurs in SMEs. "Education and Training", 44(8/9).

Dibella, A., Nevis. E. C., Gould, J. M. (1996). Understanding organizational learning capability. "Journal of Management Studies", 33.

Dyer, W. (1985). The cycle of cultural evolution in organisations [In:] Kilmann, R., Saxton, M., Serf, A. R. ed., Gaining control of corporate culture. San Francisco: Jossey-Bass, 200-229.

Finkelstein, S., Hambrick, D. C. (1996). Strategic leadership: top executives and their effects on organisations. Minneapolis/St. Paul, MN: West.

Fitza, M. (2017). How much do CEOs really matter? Re-affirming that the CEO effect is mostly due to chance. "Strategic Management Journal", 38(3).

Fitzsimmons, J. R., Steffens, P., Douglas, E. J. (2005). Growth and profitability in small and medium sized Australian firms. Melbourne: Paper presented at AGSE entrepreneurship exchange.

Fiol, C. M., Lyles, M. A. (1985). Organisational learning. "Academy of Management Journal", 10.

Garcia-Morales, V. J., Jimenez-Barrinonuevo, M. M., Gutierrez-Guttierrez, L. (2011). Transformational leadership influence on organizational performance through organizational learning and innovation. "Journal of Business Research", 65.

Glynn, M. (1996). Innovative genius: A framework for relating individual and organizational intelligences to innovation. "The Academy of Management Review", 21(4).

Hambrick, D. C., Mason, P. A. (1984). Upper echelons: the organization as a reflection of its top managers. "Academy of Management Review", 9.

Hambrick, D. C. (2007). Upper echelons theory: An update. "Academy of Management Review", 32.

Harbone, P., Johne, A. (2003). Creating project climate for successful product innovation. "European Journal of Innovation Management", 6(2). 
Haveman, H. A. (1992). Between a rock and a hard place: Organizational change and performance under conditions of fundamental environmental transformation. "Administrative Science Quarterly", 37(1).

Hitt, M. A., Keats, B. W., DeMarie, S. M. (1998). Navigating in the new competitive landscape: Building strategic flexibility and competitive advantage in the $21^{\text {st }}$ century. "Academy of Management Executive”, 12.

Hurley, R. F., Hult, G. T. (1998). Innovation, market orientation, and organizational learning: an integration and empirical examination. "Journal of Marketing”, 62.

Ireland, R. D., Hitt, M. A. (1999). Achieving and Maintaining Strategic Competitiveness in the 21st century: The Role of Strategic Leadership. "Academy of Management Executive", 13(1).

Janicijevic, N. (2012). The influence of organizational culture on organizational preferences towards the choice of organization change strategy. "Economic analysis", 47 LVII(193).

Jones, G. (1983). Transaction costs, property rights, and organisational culture: An exchange perspective. "Administrative Science Quarterly", 28.

Joseph, K. E., Dai, C. (2009). The influence of organizational culture on organizational learning, worker involvement and worker productivity. "International Journal of Business and Management", 4(9).

Kamariah, N., Rahman, A., Kadir, I. A. (2018). Mediation effect of dynamic capability in the relationship between knowledge management and strategic leadership to organizational performance accountability. "International Journal of Law and Management", 60(2).

Katila, R., Shane, S. (2005). When does lack of resources make new firms innovative? "Academy of Management Journal", 48.

Knies, E., Jacobsen, C., Tummers, L. G. (2016). Leadership and Organizational Performance: State of the Art and Research Agenda [In:] Storey, J., Denis, J. L., Hartley, J., Hart, P., eds., Routledge Companion to Leadership, London: Routledge.

Kotter, J. P., Heskett, J. L. (1985). Corporate Culture and Performance. New York: The Free Press, 1992

Markman, G., Gartner, W. (2002). Is extraordinary growth profitable? A study of incorporated. 500 high-growth companies. Entrepreneurship Theory and Practice, 27(1).

McDermontt, R., O’Dell, C. (2011). Overcoming cultural barriers to sharing knowledge. "Journal of Knowledge Management", 5(1).

Namada, J. M. (2017). Organisational learning and firm performance: An empirical investigation in an emerging economy context. "International Journal of Business, Social Sciences studies and Research", 1(1).

Oladele, P. O., Akeke, N. I., Adebisi, S. O., Adeusi, S. O. (2013). Effects of strategic leadership styles on organizational development of SMEs in Lagos, Nigeria. "Net Journal of Social Sciences", 1(2).

Papadakis, V., Bourantas, D. (1998). The chief executive as corporate champion of technological innovation: An empirical investigation. "Technology Analysis and Strategic Management", 10(1).

Phipps, K. A., Burbach, M. E. (2010). Strategic leadership in the non-profit sector, opportunities for research. "Journal of "Behavioural and Applied Management", 11(2).

Quigley, T. J., Graffin, S. D. (2017). Reaffirming the CEO effect is significant and much larger than chance: A comment on Fitza (2014). "Strategic Management Journal", 38(3). 
Safarzadeh, T., Dahghan, E., Pazireh, M., Pouraskari, F. (2015). Checking the relationship between strategic leadership, competitive advantage and organizational performance with mediating role of innovation. "International Journal of Business and Behavioural Science", 5(1).

Senge, P. (1990). The fifth discipline: The art and practice of the learning organisation. New York: Doubleday.

Sethi, R. (2000). New product quality and product development teams. "Journal of Marketing”, 64.

Slater, S., Narver, J. C. (1995). Market orientation and learning organization. "Journal of Marketing”, 59, July.

Slawinski, N. (2007). Strategic leadership [In:] Rowe, W. G., Oaks, Th., eds, Cases in leadership. CA, New York: Sage Publications.

Strand, R. (2017). Strategic Leadership of Corporate Sustainability. "Journal of Business Ethics”, 123(4).

Waldman, D., Ramírez, G., House, R., Puranam, P. (2001). Does leadership matter, CEO leadership attributes and profitability under conditions of perceived environmental uncertainty. "Academy of Management Journal”, 38(4).

Yazdani, M. (2009). Offering process model to application of knowledge management, based on organizational learning. "Journal of IT management", 1.

Yesil, S., Kaya, A. (2013). The effect of organizational culture on firm financial performance: Evidence from a developing country. "Procedia-Social and Behavioural Sciences", 81.

Yukl, G. (2010). Leadership in organisations. New Jersey: Pearson.

Zollo, M., Winter, S. G. (2002). Deliberate learning and the evolution of dynamic capabilities. "Organisation Science", 13.

DOI: $10.7862 /$ rz.2021.mmr.13

The text was submitted to the editorial office: July 2021.

The text was accepted for publication: September 2021. 
